\title{
NOTES FROM UGANDA NATIONAL PARKS
}

\section{(From Reports by the Director)}

Research.-The Fulbright organization in the U.S.A. has provided three experienced scholars to study biological problems in the Parks and they commenced work in October, 1956. Dr. Hal Buechner is working the Murchison Park studying, in particular, the Uganda kob and elephant migration. Dr. George Petrides and Dr. Wendell Swank are working the Queen Elizabeth Park on the hippopotamus population and the general effect of the grazing and browsing animals on the vegetation which is their food supply. Meanwhile Dr. Hugh Cott from Cambridge has continued his work on crocodiles.

Work in the Queen Elizabeth Park has been done also by Mr. Allan Brooks, the Game Department biologist.

\section{Queen Elizabetir Park}

Elephants. - A mother elephant and her new born baby were found in one of the deep borrow pits beside the new road. The mother became very agitated at the approach of the Warden's Land Rover and tried her best to assist the new born baby up the bank and across the road, but was most unsuccessful for the calf was extremely weak. Then three adult elephants broke cover on the opposite side of the road and made straight for her. They practically lifted the young one up the bank and onto the road by putting their trunks under his rear quarter and pushing him like a wheel barrow. Once he was on the road, they formed up on either side and escorted him across : once across, the mother was again left in sole charge and the three rescuers disappeared towards the lake.

Buffalo.-Two very tame herds of buffalo exist in the Nyamagasani area of the Queen Elizabeth Park. Both herds have a proportion of the red coloured beasts and all the animals are in first class condition. By a careful approach one can get within twenty yards of the herds and frequently some of the animals don't even stand up. Others will move towards the vehicle and come within fifteen yards.

\section{Murcinison Park}

Elephants.-The " Lord Mayor of Paraa " continued to cause trouble to the water supply and has learnt how to turn the main tap. This should perhaps be taken as evidence of a personal interest in municipal affairs, rather than a destructive habit 
of mind, as no doubt "His Worship" likes to see for himself how the services are operating. That he takes his official position seriously and is much concerned over precedence was shown during the visit by H.E. the Governor and the Governor of Ruanda-Urundi. On this occasion the "Lord Mayor" refused to allow the visitors to leave the landing stage and drive into his city, the Paraa Safari Lodge, although this was eventually achieved by a somewhat undignified and surreptitious move through the yard at the back of the workshop.

It is well known that in London the Sovereign must obtain formal sanction of the Lord Mayor before crossing the boundaries of the City and a similar custom prevails at Paraa. The organizers of this visit had failed signally in their duty in that they had given no previous notification to the "Lord Mayor of Paraa" or approached him for authorization of IHis Excellency's entry.

Buffalo.-One evening in March, a ranger reported that he had seen four buffalo trapped in a murrum pit near the track to Wangkbar. The Warden, Mr. Cottingham, Assistant Warden Odur and four rangers, hurried to the spot with as much rope as they could lay hands on, a Land Rover and a lorry. They found one full grown female buffalo, two half grown males and a young calf inextricably mixed up in the pit, the bottom of which was a quagmire of mud. The calf was lying on its side being trampled on by the others, the cow in particular making frenzied efforts to extricate herself. She could get her front legs onto the lip of the pit but lacked purchase for her hind legs in the mud.

When the Warden and his party arrived, the scene in the pit became one of utter confusion. Attempts were made to help the animals to get themselves out by placing tree trunks and so forth in the pit, but the buffalo would not co-operate.

Eventually it was decided that the only hope was to use the ropes and try to pull the animals out, and to this end the lorry was backed up to the pit. One of the young bulls was then lassoed round the horns, and pulled out resisting hard. Having charged the lorry as a mark of thanks, he went off. The process was repeated with the second youngster, with the same results. The cow presented a more formidable problem. This time a much heavier rope was used, but once she was lassoed the combined efforts of the rescuers were insufficient to drag her out. She was eventually towed out by moving the lorry slowly forward, whilst the men in the back hauled on the rope. Once extricated and the rope having been cut she made a valiant attempt to 
charge, but her carlier efforts had so exhausted her that her rear legs crumpled up. However ten minutes later she was on her feet, full of malevolence, and eventually made off, into the bush, with the rope still round her horns. The calf by this time was scarcely conscious, and having been lassoed, had to be dragged out of the mud by main force. As it was now nearly dark and the calf showed no signs of revival, it was thought better to despatch it, than to leave it to the night.

By reconstructing the incident from the spoor, it seems that the calf fell in first, followed by the cow, who must have been its mother. The rest of the herd had obviously milled around the pit and the two inquisitive youngsters had probably been accidentally pushed in. It was felt that by rescuing three out of four of the animals, honour had been sustained and the ideals of the National Parks maintained. 